\title{
Readiness of East Java MSMEs Bank in Implementing Crowdfunding
}

\author{
Sentot Imam Wahjono ${ }^{1}$, Anna Marina ${ }^{2}$, Soo-Fen Fam ${ }^{3}$, Ismail Rasulong ${ }^{4}$ \\ \{sentot.imamw@fe.um-surabaya.ac.id ${ }^{1}$, anna.marina@fe.um-surabaya.ac.id ${ }^{2}$, famsofeen@utem.my ${ }^{3}$, \\ ismail.rasulong@unismuh.ac.id $\left.{ }^{4}\right\}$
}

Fakultas Ekonomi dan Bisnis, Universitas Muhammadiyah Surabaya ${ }^{12}$, Fakulty of Teknology Management and Technopreneurship, Universiti Teknikal Malaysia Melaka, Malaysia ${ }^{3}$, Fakultas Ekonomi dan Bisnis,

Universitas Muhammadiyah Makassar, Indonesia ${ }^{4}$

\begin{abstract}
Crowdfunding is a financial terminology for funding businesses with an internet base that is suitable for MSMEs. This study aims to determine the readiness of the East Java MSMEs bank in implementing crowdfunding. The research approach used is Mixed Method. Quantitative data was collected after distributing online questionnaires to members of Facebook crowdfunding in Indonesia, as many as 45 sets of answers were analyzed descriptively by giving grades from 1 (not ready) to 10 (very ready). The questionnaire refers to the InfoDev indicator. Qualitative data were obtained by interviewing 6 bank officials about the 6 indicators of readiness to refer to Sancak. This study found evidence that MSMEs banks were ready to implement Crowdfunding even though it was still at an early stage. Much effort is needed to prepare banks to become better equipped with the adoption of the RSC to protect investors or donors.
\end{abstract}

Keywords: Crowdfunding; SMEs; BPR; readiness, RSC.

\section{Introduction}

MSMEs in Indonesia have a large role in terms of employment $(89.2 \%)$, contributing to GDP $(60.34 \%)$, to exports $(14.17 \%)$, to national investment of $58.18 \%$ [1]. MSMEs are also a potential market for the financial services industry for channeling financing or credit because $70 \%$ of MSMEs do not have access to bank loan [2]. Likewise the large role of MSMEs appears to be large in East Java Province [3].

MSMEs are still difficult to get funding from banks and other financial institutions [4]. This condition does not only occur in Indonesia and other developing countries but also occurs in European countries. Ryan et al [5] states that the stronger the market share of a bank the more obstacles the bank is channeling loan to MSMEs. The study used a large panel dataset of more than 118,000 SMEs in 20 European countries during the 2005-2008 period. Due to the difficulty of getting funding from banks, MSMEs tend to use trade credit to finance working capital needs and even investment needs [6]. The use of trade credit to meet working capital and investment certainly has an impact on the high cost of funds [7]. Given the difficulty of MSMEs in getting funding from banks and other financial institutions, alternative funding providers are needed to support MSME funding [8]. Indonesia [9] and several ASEAN countries apparently considered Crowdfunding to be 
a source of funding for SMEs and business startups [10]. The appropriate funding institution to fund MSME businesses is the Rural Bank, in Indonesia called the Rural Credit Bank or BPR [11].

The East Java UMKM Bank is a BPR owned by the East Java provincial government, which specializes in serving MSME business activities in East Java wanting to be more involved in providing funding services through crowdfunding mechanisms. Based on this, this paper intends to find out the readiness of the MSME Bank in implementing Crowdfunding.

\section{Literature Review}

Crowdfunding is a financial term to recover after the financial crisis in 2008 as an alternative funding/capital for new businesses around the world [8]. According to the World Bank [12], crowdfunding can describe as a fatherly way to use internet businesses and organizations to obtain money (capital). Ranging from the US\$1,000 until the US\$1 million in contributions or investments from various parties. Crowdfunding is an online-based on a finance extension that was founded by friends and family, community premises other words that raise money to fund members joined, and have a business idea.

Crowdfunding is an innovation in entrepreneurial finance that can trigger a "Resurgence of Rest" globally. Crowdfunding can create focus and action in cities and towns, to form an entrepreneurial ecosystem that can trigger innovation, create jobs and grow the economy [12]. In the past, due to the high cost of technology development, lack of cellular / web infrastructure and limited financial regulations, entrepreneurs had to travel to places like Jakarta to find technology and investors to build their companies. For most, this is expensive and logistically impossible. The crowdfunding mechanism is shown in figure 1.

A study on the readiness of an institution to implement crowdfunding has been carried out by the World Bank [12] by setting 4 specific strategies to drive crowdfunding: Economics, Social, Technology, and Cultural. Economic indicators consist of Craft exceptions to securities regulations that allow easy registration for equity and the debt crowdfund offerings, Strategically tie crowdfunding to patriotic and cultural messages, Form a crowdfunding market alliance. Social indicators consist of Harness top social media experts / bloggers / tastemakers to communicate with local audiences and with diaspora audiences, Hold media and educational events to build awareness and understanding, Hold regular crowd funding events with trusted third parties to teach successful techniques. Technology indicators consist of Where appropriate, apply lessons learned from developed world, Consider buy, build or white label, Determine gaps in technology for online financial transactions. Cultural indicators consist of leverage leverage incubator / accelerator / structured co-working spaces as hubs for innovation in funding, Foster professional investors \& consumer confidence in crowd funding through education and communication [13].

Sancak [14] who examined the readiness of the Turkish state to implement Crowdfunding. This study was conducted using a mixed method. A qualitative approach was carried out by interviewing 4 experts who were considered to understand crowdfunding in Turkey. They are capital market professionals, a former director at the Banking Regulatory and Supervisory Agency of Turkey. There are 6 open and closed questions regarding the readiness to implement crowdfunding. Wahjono et al, [13] examined the readiness of Muslim countries to fund SMEs through crowdfunding. The 
research method used is qualitative research, data obtained using database analysis. The findings of this study indicate that there are 6 out of 9 Islamic countries that are ready to implement crowdfunding, namely Malaysia, Indonesia, Jordan, Lebanon, Tukey, and the UAE while 3 other Muslim countries namely Egypt, Iran, and Saudi Arabia are still not ready to carry out crowdfunding to finance MSMEs.

The readiness of ASEAN countries in implementing crowdfunding in funding SMEs shows the results that 5 ASEAN countries namely Indonesia, Malaysia, the Philippines, Thailand and Vietnam are ready to implement crowdfunding. Malaysia is the country most ready to run crowdfunding [9]. This research uses a qualitative approach, using database analysis. Analysis was carried out in two aspects, namely entrepreneurship culture factors and internet network readiness. Based on a global report released by the 2016 global entrepreneurship monitor and when a network readiness analysis is based on a 2015 global information technology report, states in the five countries show that crowdfunding can be carried out successfully but not to be used as an alternative to financing business related to SMEs [15].

Crowdfunding implementation is very important to improve financing capabilities for small or new ventures in developing countries [16]. As the growth of financial capabilities is a significant change and unstable in the country's economy, the number of entrepreneurs is the factor affecting the growth [17]. Even in Asia and South America, crowdfunding is still in the growing stage, and factors that influence is the technology itself and how fast the implementation will take [18]. Therefore, the researcher stresses the readiness for BPR to implement crowdfunding as the main proposed of this research.

\section{CROWDFUNDING MECHANISM}

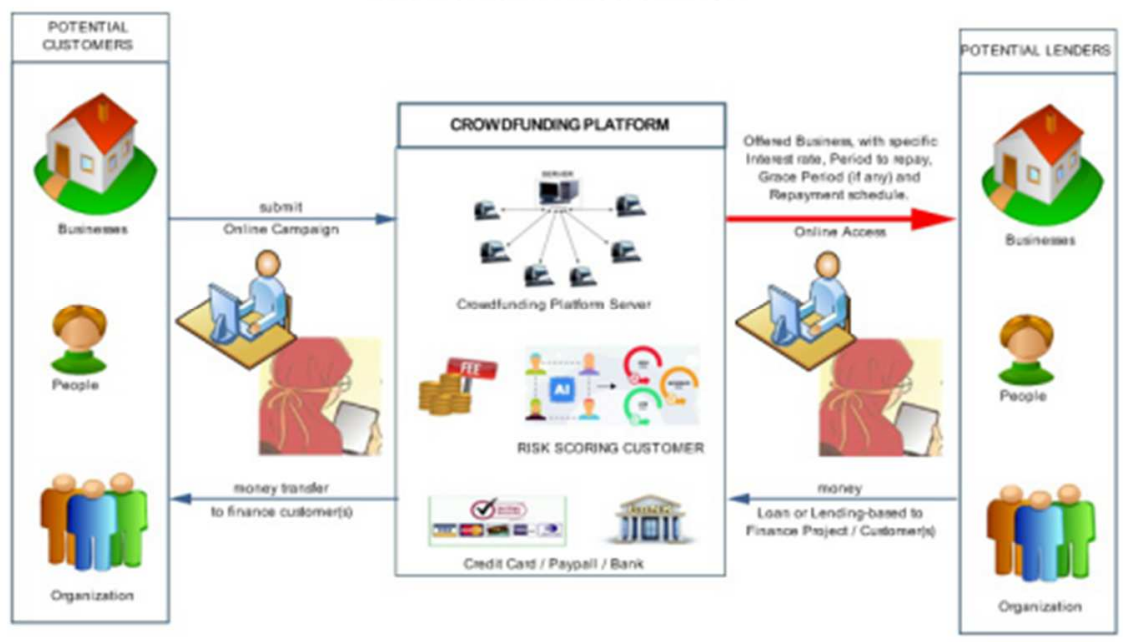

Fig.1. Crowdfunding Mechanism 


\section{Method}

This study uses a mixed with embedded design approach where quantitative data is collected prior to qualitative data collection. Interpretation is done by using an embedded design that combines quantitative data collected first with qualitative data collected later [19] as shown in Figure 2.

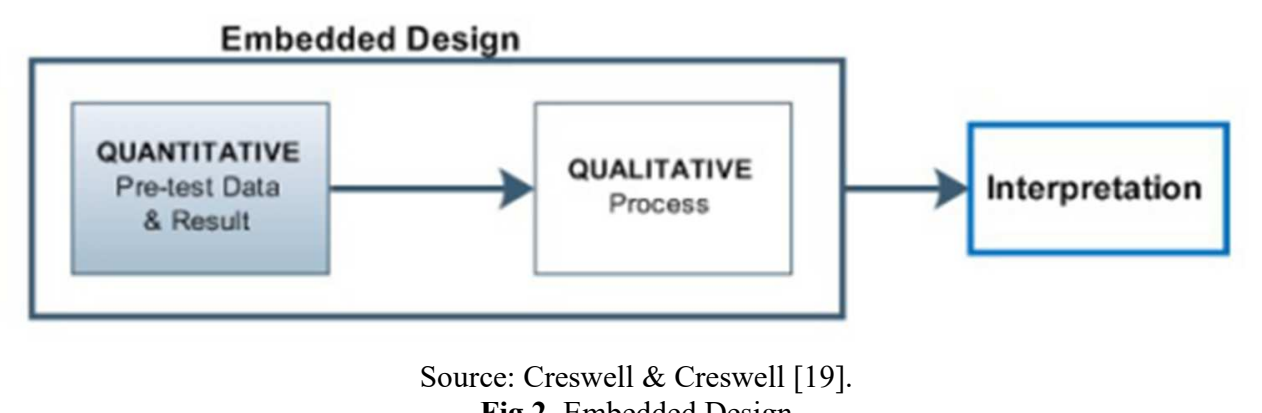

The questionnaire to collect quantitative data was compiled based on the World Bank Report on Crowdfunding's Potential for the Developing World [12]. The findings of this study in the form of the readiness of the East Java MSME bank in implementing crowdfunding are presented in the form of radar which includes 9 indicators, 4 quantitative indicators and 5 qualitative indicators. Respondents were selected from a collection of social media groups relevant to crowdfunding with the filter question "do you know and understand crowdfunding?" 45 people met the filter criteria and returned the questionnaire sent online using Google-form. Qualitative data were obtained by conducting interviews with 6 UMKM Bank officials namely Managing Director, Marketing Director, General Director, and Compliance Director, Head of Information Technology Subdivision, and Supervisor Development. Interview guide refers to Sancak [14].

\section{Result And Discussion}

Quantitative and qualitative data that is entered are processed to be described and displayed on the radar. Data for each indicator, respondent, and informant are averaged so that they appear as in table 1 and figure 3. Table 1 shows that the Technology indicator (technology and education level) has an average value of 6.25, while the indicators for Entrepreneurial Culture (including whether entrepreneurship is considered a career path that has a good reputation?) Have an average value of 5.03. Regulation indicators (including regulations can enable and prevent entrepreneurship and crowd funding depending on the structure and scope) have an average value of 5.38, Economy (capital) indicators have an average value of 5.10, Optimism Indicators from Bank of East Java SMEs officials have values an average of 6.11, Financial Regulation Indicators (including the financial, legal and economic environment now conducive to crowdfunding?) have an average value of 6.00, the Investor Protection indicator has an average value of 3.17, the Benefit for SMEs indicator has an average value average of 5.25, while the Obstacle to Implementing indicator has an 
average value of 3.83. from 9 indicators of readiness for crowdfunding implementation at SMEs Bank, it has an average value of 5.12 .

Tabel 1. The Score of Readiness Indicator

\begin{tabular}{lc}
\hline \multicolumn{1}{c}{ Readiness Indicator } & Average \\
\hline A. Technology & 6,25 \\
B. Entrepreneurial Culture & 5,03 \\
C. Regulation & 5,38 \\
D. Economy & 5,10 \\
E. Optimism & 6,11 \\
F. Financial Regulation & 6,00 \\
G. Investor Protection & 3,17 \\
H. Benefit for SMEs & 5,25 \\
I. Obstacle to Implementing & 3,83 \\
\hline \multicolumn{1}{c}{ Readiness } & $\mathbf{5 . 1 2}$ \\
\hline \multicolumn{2}{c}{}
\end{tabular}

Quantitatively, the value of the East Java MSME bank readiness to implement the highest crowdfunding is an indicator of Technology. This high value was contributed by the internet / smartphone penetration level sub-indicator and the banking system sub-indicator that supports electronic funds transfer. Qualitative data shows an optimism indicator contributing the highest value (6.11). This score shows the confidence of informants about the effectiveness of crowdfunding in funding MSMEs, and the ability of banks to educate and educate customers through crowdfunding mechanisms, as well as the opening of women's participation in crowdfunding.

READINESS OF IMPLEMENTATION

CROWDFUNDING AT BANK UMKM JATIM

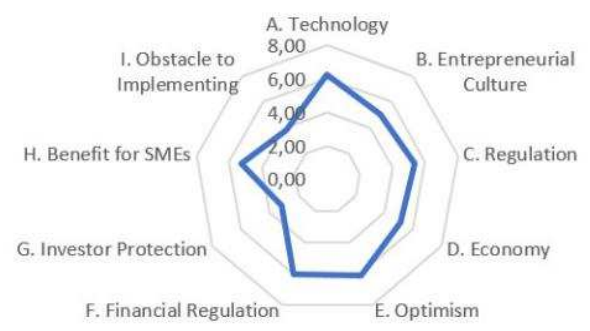

Fig.3. Readiness of Implementation Radar

The findings of this study indicate that the readiness of the East Java MSME bank in the initial stages is at a score of 5.12 from the maximum value of 10.00 . This readiness score indicates the need to increase efforts in entrepreneurial culture, regulation, and economic conditions conducive to cashless virtual economic transactions. This finding is in line with InfoDev [15] and also Wahjono et al [13]. This finding is also in line with the World Bank study [12] which states that readiness to implement crowdfunding depends a lot on internet and smartphone penetration because of internetbased crowdfunding [9] also Putra et al, [7]. The findings of this study will be faced with the findings of World Economy Forum [12] which states that the most difficult challenge in implementing 
crowdfunding is the availability and mastery of ICT, even though the technology score of this study is quite large, 6.25.

Qualitatively the highest score is optimism which draws the informants' subjective beliefs that still need proof and has the potential to change depending on the holders of key positions in the East Java UMKM bank. When directors' optimism is high, readiness to implement crowdfunding is high. This finding is in line with Sancak [14] and Wahjono et al [8]. This optimism needs to be built by the Board of Directors to encourage crowdfunding implementation to enlarge the assets of the current MSME bank of Rp 2.6 trillion, because crowdfunding is the best choice for raising rural bank assets [11]. The research findings show that the perception of directors is low on investor protection with a score of 3.17 from the maximum value of 10.00. This finding is not in line with Cumming \& Zhang [18] which states that crowdfunding is the best platform to protect investors in developing countries. This finding is also in line with Bagheri et al [17] which states that crowdfunding is the best platform that focuses on donor or investor perspectives.

\section{Conclussion}

This study found evidence that MSME bank readiness is at a low score even though it can be said to be ready. A lot of effort is needed to better prepare a number of things in implementing crowdfunding.

The findings of this study stated that the East Java UMKM bank was ready to implement crowdfunding even in the initial stages because the score was low despite being above 5.12. This study recommends the Directors of the Bank of UMKM East Java and also the Government of East Java Province as the largest shareholders to prepare especially in terms of preparing regulations in terms of protection for investors and donors and overcoming various obstacles in implementing crowdfunding including mental preparation of the community that all transactions in the crowdfunding safe and fast, including by adopting RSC (risk scoring customer) to accelerate the process of channeling funds to MSMEs, this is also to answer the challenge that this crowdfunding is an appropriate funding platform and is very useful for MSMEs.

\section{References}

[1] S. N. Sarfiah, H. E. Atmaja, and D. M. Verawati, "UMKM Sebagai Pilar Membangun Ekonomi Bangsa,” J. Ris. Ekon. Pembang., vol. 4, no. 2, pp. 41-52, 2019.

[2] lies M. Hamzah and D. Agustien, "Pengaruh Perkembangan Usaha Mikro, Kecil, Dan Menengah Terhadap Pendapatan Nasional Pada Sektor Umkm Di Indonesia," J. Ekon. Pembang., vol. 8, no. 2, pp. 215-228, 2019.

[3] H. Yoka Roida, N. A. Sunarjanto, and W. Jayaprana, "Internasionalisasi usaha mikro, kecil, dan menengah (umkm) ditinjau dari tipe kepemilikan: studi empiris di jawa timur," J. Manaj. Teor. dan Terap., no. 2, pp. 158-170, 2010.

[4] C. Nisa, "Analisis dampak kebijakan penyaluran kredit kepada umkm terhadap pertumbuhan pembiayaan umkm oleh perbankan," DeReMa J. Manaj., vol. 11, no. 2, pp. 213-234, 2016, doi: 
10.1007/978-3-642-17851-1_35.

[5] F. M. Robert M. Ryan, Conor M. O’Toole, "No Title," J. Bank. Financ., vol. 49, no. December, pp. 495-505, 2014, doi: https://doi.org/10.1016/j.jbankfin.2013.12.024.

[6] C. M. O. Eddie Casey, "Bank lending constraints, trade credit and alternative financing during the financial crisis: Evidence from European SMEs,” J. Corp. Financ., vol. 27, no. August, pp. 173-193, 2014, doi: https://doi.org/10.1016/j.jcorpfin.2014.05.001.

[7] P. O. Hadi Putra and H. B. Santoso, "Contextual factors and performance impact of e-business use in Indonesian small and medium enterprises (SMEs)," Heliyon, vol. 6, no. 3, p. e03568, 2020, doi: 10.1016/j.heliyon.2020.e03568.

[8] S. I. Wahjono, A. Marina, M. Fikry, and . A., "Innovative funding solution for special projects: Crowd funding," J. Econ. Bus. Account. Ventur., vol. 18, no. 1, p. 65, 2015, doi: 10.14414/jebav.v18i1.383.

[9] S. Imam Wahjono, A. Marina, S. Shahmi Sezeli, and B. W. Mahardika, "THE ROLE OF SOCIAL AWARENESS OVER THE SUCCESS OF CROWDFUNDING PLATFORM," Humanit. Soc. Sci. Rev., vol. 7, no. 3, pp. 534-540, May 2019, doi: 10.18510/hssr.2019.7379.

[10] M. Md Husin and R. Haron, "Financial Sustainability of SMEs Through Islamic Crowdfunding," no. December, pp. 321-337, 2020, doi: 10.4018/978-1-7998-0218-1.ch018.

[11] Wasiaturrahma, R. Sukmana, S. R. Ajija, S. C. U. Salama, and A. Hudaifah, "Financial performance of rural banks in Indonesia: A two-stage DEA approach," Heliyon, vol. 6, no. 7, p. e04390, 2020, doi: 10.1016/j.heliyon.2020.e04390.

[12] World Bank, "Crowdfunding's Potential for the Developing World," Financ. Priv. Sect. Dev. Dep., pp. 1-102, 2013.

[13] A. Wahjono, Sentot Imam \& Marina, CROWDFUNDING, Suitability to Finance Islamic Project or Business. Saarbrucken, Germany, 2016.

[14] I. E. Sancak, "Applicability and Readiness of Crowdfunding in Turkey,” Int. J. Bus. Soc. Sci., vol. 7, no. 1, pp. 99-110, 2016.

[15] World Economic Forum and INSEAD, The Global Information Technology Report 2016, 2016 th ed. Geneva: World Economic Forum and INSEAD, 2016.

[16] Jacob Hörisch, "Take the money and run? Implementation and disclosure of environmentally-oriented crowdfunding projects," J. Clean. Prod., vol. 223, no. June, pp. 127-135, 2019, doi: https://doi.org/10.1016/j.jclepro.2019.03.100.

[17] Afsaneh BagheriHasti ChitsazanHasti ChitsazanAshkan Ebrahimi, "Crowdfunding motivations: A focus on donors' perspectives," Technol. Forecast. Soc. Change, vol. 146, no. June, pp. 218-232, 2019, doi: 10.1016/j.techfore.2019.05.002.

[18] Douglas Cumming \& Yelin Zhang, "Alternative investments in emerging markets: A review and new trends," Emerg. Mark. Rev., vol. 29, no. December, pp. 1-23, 2016, doi: https://doi.org/10.1016/j.ememar.2016.08.022.

[19] J. D. Creswell, John W., Creswell, Research Design. Qualitative, Quantitative, and Mixed Methods Approaches., Fifth. London, 2018. 